\title{
生理心理機能の統合的時系列解析による 疲労判定に関する研究"
}

\section{吉村 勲**，友田泰行**}

This paper describes integrated estimation and consideration of the fatigue happening period by the three sides-changes of physiological function, operation capacities, and investigation of subjective symptoms.

In this experiment, 15 subjects does continuously the combination VDT work comparison and reference for 90 minutes. For this time, each physiological functions in the system of vascular and the system of myotonic frames are expressed by standard score. So, it's possible to estimate the fatigue by the same scale and judge to the function changes clearly. Concretely, that is decided by the timephase transition of the standard score average and standard deviation.

As a result, judging the physiological function by standard deviation, that has the tendency to disorder the constancy clearly, at 40 or 50 minutes after the experiments started. While, judging by average, that tendency appeares at about 60 minutes.

Synthesizing these results, operation capacities, and investigation of subjective symptoms, it's possible to decide that scene as fatigue appearence period. At last, this way is considered effective.

産業行動の場における疲労発現と思われる時期を統合的に評価・判定するために，照合および検索 を組み合わせたVDT 作業を設定し, 作業者の生理的機能変動, 作業能, 自覚症状の 3 側面から検討を 行った.

生理的機能は，心臓血管系と筋骨格系における各指標を標準得点化することで同一尺度評価が可能 となり，機能変動がより明確なものとして判定できた．標準得点の平均值，標準偏差の時系列推移か ら判断すると, 標準偏差で開始後 40 分から 50 分頃, 平均値で 60 分頃が生理的機能の恒常性の乱れに 明確な傾向を示す時期と考えられる. 以上の結果と, 作業能, 自覚症状調査を総合すると, この時期 を疲労発現期と結論することが可能となり，本方法での有効性が示唆された。

(キーワード：疲労, 生理, 測定法, 一連続作業)

\section{1. はじめに}

労働は価値増殖過程と生産過程の 2 つの側面をもち, 能率や安全性の向上,さらに健康の維持・増進など社 会的な意義と密接な関係のうえに成り立うているとい われる。したがって, 労働の過程で生起する (産業) 疲

* 平成 4 年 7 月 2 日受付

** 関西大学 工学部

Faculty of Eng., Kansai Univ.
労は生体内での機能変動だけでなく，経済的・社会的 な現象でもあると考えられる。近年，急テンポの技術 革新, 情報化のもと, VDT を中心とした機器があらゆ る職場で導入・活用されている。それらは処理・応答 において秒単位以上の速さをもち，意思決定やデー夕 のやりとりなどがネットワーク化され，作業者は席を 離れることなく仕事を遂行する状況が多くなり，高い 生産性が期待されている。一方，障害のある人や高齢 者など, 広い範囲での就業の機会となり, 筋力, 熟練 度，健康状態および身体条件などに応じ，就業・持続 
できる作業環境・条件の構築が求められている1).

しかしデータ検索型 VDT 作業では, 連続 1 時間を 超える作業継続となる場合が $80 \%$ 以上で, 1 日の平均 VDT 作業時間は $4 \sim 6$ 時間が最多 ${ }^{2)}$ といわれる.さら に, 上肢の静的筋労作の反復, 高密度神経緊張の連続, 拘束姿勢の持続や蛍光発光文字の注視などといった条 件のもと, 眼精疲労や視機能の障害, 頸肩腕 - 背腰障 害, 自律神経失調やストレス性疾病などの原因 ${ }^{3 \sim 5)}$ と なり, それらは動的筋労作における肉体疲労に加え, 局所疲労や精神疲労要素の強い発現6)になるとされて いる.これらの作業における疲労問題は, 一連続作業 時間や総作業時間および休噁時間とともに，その定量 的判定・評価問題が提起されて久しい.

疲労の評価については数多くの研究が行われている

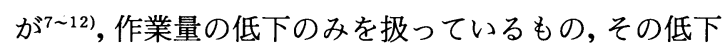
のメカニズムを考元恒常性の乱れによるとするもの, 低下の現象を生体が過度の損耗に陥らないための防御 機構であるとするものなど, その結果の客観性におい て一面的で, そのときの疲労状態・状況の確認などに は詳しく触れられていない.

Bills $^{13)}$ は, 疲労それ自体を測定することは難しい が, “自覚的なもの, 客観的なもの, 生理学的なもの” の 3 つの側面から評価できるとし, 関係する現象や状 況の 3 側面を測定・把握することによって疲労の判定

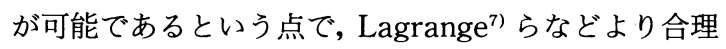
的であると考えられる. さらに橋本 ${ }^{14)} も$, 主観的指標 として疲労感, 客観的指標として出来高の量的・質的 な低下と作業能力の低下, および生理的機能の低下の 3 つの指標で判定するのが妥当とし, 大島 ${ }^{15)}$ は, 生体 になんらかのひずみが起こり, 生理的活動に変化をき たし, 機能の変化, 物質の変化, 主観的訴え, 能率の 変化などを生ずるものと定義している，これらにはま だ観念的な部分なども残ると考えられるが, 疲労の定 義としてはより合理的で, 客観的・分析的に理解する うえで大きな方向性を示すものと考えられる.

人間は物質代謝を常時安定した状態で行うために, 循環器系, 内分泌系, 自律神経系, および体性神経系 の 4 つの調整系が活動し, そのレベルが多少変動して も, それぞれの機能をほほ一定の範囲に維持しょうと する適応能力 (恒常性)をもち ${ }^{16)}$, これら生体調節系の 相互関連のもとに産業行動が円滑に行われると推測さ れる.しかし活動レベルがより大きく変化し, 生体に とって過度の負荷・負担となると, それらの適応能力 が低下し, 恒常性が乱れ, 機能の調整もとれなくな $\eta^{15)}$, 疲労の発現に大きく関係するものと考えられる. よって, 生理的機能として自律神経系の支配を受ける 循環・呼吸器系と, 筋骨格系の両側面から関連する機
能を測定評価することで，主題に迫ることが可能であ ると考えられる.

本論では, 疲労は精神機能の低下と身体機能の低下 が統合された生体反応の結果であるとの斎藤 ${ }^{17)}$ の考 えを基本に，それらの低下には単なる機能低下だけで なく,リズムやその機能変動の大きさも関係している と仮説した．また，機能によっては六進を示すなど統 一された変化とはならない部分が存在することが，よ り人間的（現実的）であると考え，その変動傾向パ夕 ーンなどを統合化することで, より明確な立場で疲労 判定を行うことを目指している.しかし，機能変動デ 一夕を単一的あるいはそのまま総合化して評価するだ

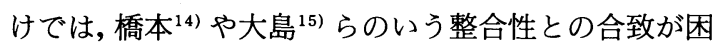
難で, それらの総合判定の方法にも明確さがそしく, 評価・判定に迫る大きな障害になっていると考える. そこで筆者らは，各機能デー夕を同一評価尺度デー夕 に変換・統合化できれば, より明確な機能変動評価が 可能であると仮定した．加えて，それらの統合デー夕 性状と作業能, 主観的疲労感に対応関係が認められる ならば, 各機能変動デー夕の同一尺度化による疲労判 定の有効性が立証できると仮説した。

\section{2. 方 法}

実験は, 実際の労働場面における状況とは若干異な るが, 疲労の発現に関して予想されるいくつかの要因 (作業, 環境条件など) を可能なかぎり定常化し, 求め るべき主体要因について測定・検討を行った。

\section{2-1. 実験作業}

作業は, 図 1 に示すようなディスプレイ注視度の高

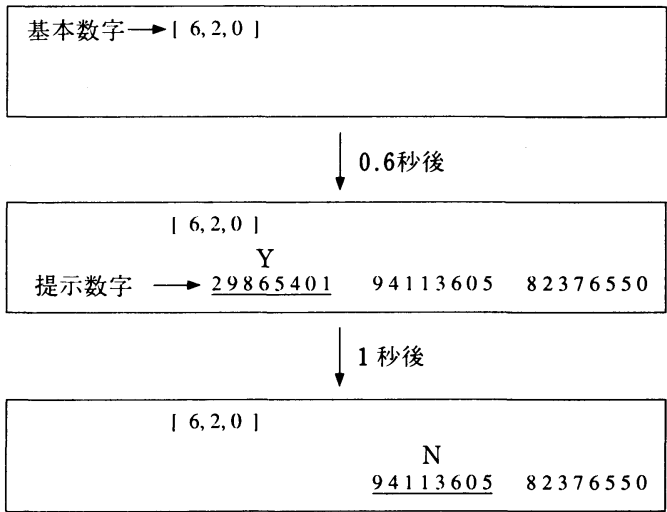

図 1 作業に用いる提示の例

Fig. 1 An example of presentations used for VDT work. 


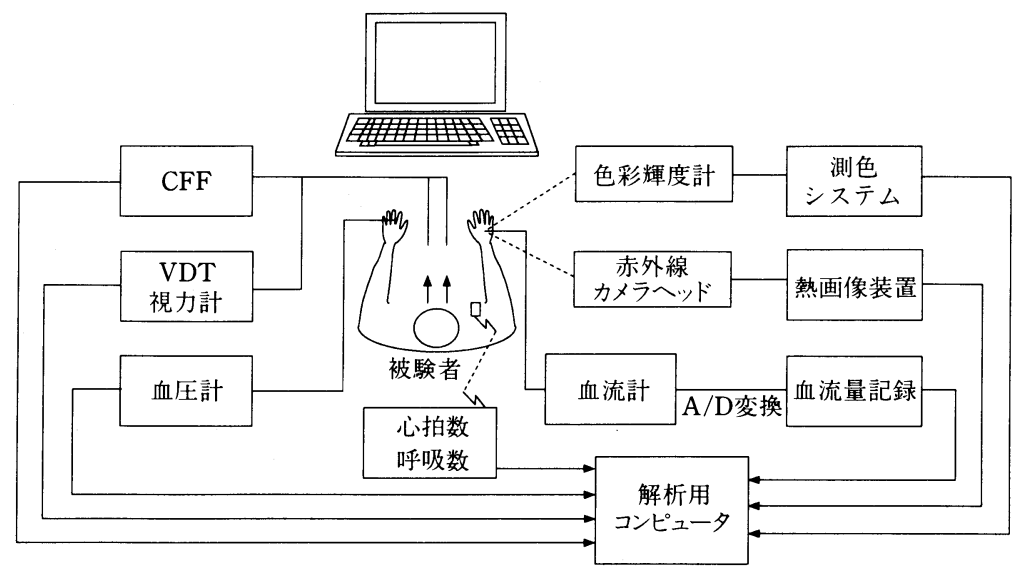

図 2 実験システム

Fig. 2 Experimental systems.

い, 照合と注意集中の必要な検索を組み合わせた VDT 作業を対象とした。すなわち, CRT 画面上に表 示された異なる 1 桁数字 3 個（基本数字）が 8 桁の数 字列 (提示数字) のなかに存在するか否かを判断し, その結果をキーボードから順次入力するものである.

提示は, まず基本数字がディスプレイ中段部左端に 0.6 秒間提示された後, ランダムな提示数字 3 組が同 時にディスプレイ中段部に表示される. 被験者は，力 ーソルによって左側から指定される提示数字について, 単位時間（ 1 秒）の間に基本数字 3 個が提示数字のな かにすべて存在するか否かを判断し, 基本数字の 3 個 が提示数字のなかにすべて存在すれば右手示指でテン キーの 5 (Yes) を, 1 個でも存在しなければ右手中指

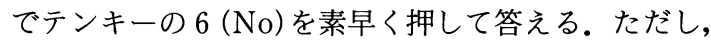
作業集中の程度を考慮して (Yes) の出現確率 (基本数 字 3 個すべてが存在する確率) は $80 \%$ と設定した。ま た, 作業者に判断動作の結果が確認できるよう, 提示 数字の中央上部に, $\mathrm{Y}$ (存在する) または $\mathrm{N}$ (存在しな い）を応答と同時に表示した。使用した機器はPC$9801 \mathrm{XL}_{2}$, CRT として 15 型フラットフェースノング レア高解像度ディスプレイ PC-KD 881 を用いた。提 示数字およびカーソルなどはすべて白で, 背景はグレ ーとした.

\section{2-2. 測定項目}

\section{（1） 生理的機能}

生理的諸機能は, 図 2 に示すような実験システムを 用いて測定を行った。循環 - 呼吸器系の心拍数, 呼吸 数, 血圧值は, 作業行動に応じて敏感に反応・変化し, 定量化しやすい. 心拍数, 呼吸数は機械的妨害が少な く, 動作時の測定に適している胸部誘電法によるテレ
メータにより計測した。血圧は直接の動作使用となら ない左手中指により無負荷動脈法で測定した.

また筋骨格系の指標は，頸肩腕障害などの原因とな る局所部での機能変動を評価するため, 非接触で客観 的評価が可能な皮膚表面温度, 皮膚色を選定した。さ らに皮膚表面温度，皮膚色は，皮膚血管を流れる血流

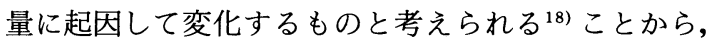
それらと同部位の皮膚血流量の測定を行った。測定部 位は図 3 に示すように作業負荷部位に近く，打鍵作業 によって頻繁に使用される右手甲部の第 2 背側骨間筋 上部を選定した。皮膚表面温度，皮膚色，および皮膚 血流量は, それぞれ熱画像装置, 色彩輝度計, レーザ スペックル血流計を用いて測定した.

中枢神経機能の評価として CFF 值を，視機能変化 についてはVDT 視力計による遠用・近用視力の測定 を行った。

\section{（2）作業能}

作業をある時間継続したときの疲労状態を示す指標 は，作業精度や作業量の低下でも評価される。今回の VDT 作業における作業能において, 基本数字がすべ て提示数字のなかに存在するとき作業者が“存在する”

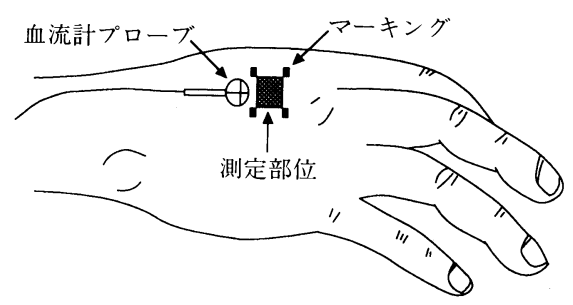

図 3 測定部位

Fig. 3 Measurement position. 
と答えた場合 $(\mathrm{Y}-\mathrm{Y})$ と，基本数字がすべて提示数字 のなかに存在しないとき作業者が “存在しない”と答 えた場合 $(\mathrm{N}-\mathrm{N})$ の両方を正答とした。また，基本数 字がすべて提示数字のなかに存在するのに “存在しな い” と答えた場合 $(\mathrm{Y}-\mathrm{N})$ と, 基本数字がすべて提示 数字のなかに存在しないのに “存在する”と答えた場 合 $(\mathrm{N}-\mathrm{Y})$ の両方を誤答とした.さらに, 提示に対し 入力がない場合を無答として集計, 処理した.

\section{(3) 主観的疲労感}

主観的な疲労感の程度を評価するために, 日本産業 衛生学会・産業疲労研究会によって作成された「自覚 症状しらべ」19)を参考に, 目的にそって削除・追加し, 図 7 に示した 34 項目を採用した。あらかじめ症状を列 挙した質問項目に対して○印で答える方式と, それら の症状を自覚した時期を段階づけする方式の 2 つの調 查法で, 作業直前・後の 2 回記入させ調査した.

\section{2-3. 実験手順}

\section{（1）実 験 I}

実験前準備として, 被験者に実験概要の説明, 生理 的機能の測定準備, 視力測定および自覚症状調査を行 つた. 実験作業時間は連続 90 分, 作業前・終了後の安 静時間はそれぞれ 30 分, 20 分とした. その間, 心拍 数, 呼吸数, 血圧值, 血流量, 皮膚表面温度, 皮膚色, $\mathrm{CFF}$ 值について 6 分間隔で測定・記録した。実験室内 の温度および湿度は $24.8 \pm 0.4^{\circ} \mathrm{C}, 32.3 \pm 1.3 \%$ で, の変動を可能なかぎりコントロールした．またキーボ 一ド上での水平面照度 $(250 l \mathrm{x})$, ディスプレイ面の鉛 直面照度 $(150 l \mathrm{x})$, 平均風速 $(0.016 \mathrm{~m} / \mathrm{sec})$ は一定に 管理した。ただし，キーボード上の水平面照度に関し ては, VDT 注視度が高く, テンキーの 5 と 6 を右手の 2 指で応答する動作で, ほとんどキーボードの確認・ 注視の必要のない視覚検索型作業であることから, 労 働省ガイドラインの下限值 $300 l \mathrm{x}$ でも明るすぎると の申告（予備実験）により若干低い值とした。被験者 らは前日までに動作習熟を終えた，21〜25 歳の健康男 子学生 15 名である.

\section{（2）実 験 II}

実験 I の結果を踏まえたうえで,一連続作業 60 分に 10 分の休息を挿入した作業を連続 5 回繰り返し行っ た. 作業前・後の安静は各 30 分とし, 合計 400 分の生 理心理機能デー夕を経時的に計測した。測定項目など は実験 I と同様とし, 測定は 10 分間隔である.

\section{3. 結 果}

各生理的機能データの作業時間別平均値および標準
偏差の変化が図 4 である. 作業能は図 5 , 図 6 に, 自 覚症状調查の結果は図 7 に示した。

\section{3-1. 生理的機能}

\section{(1) 循環・呼吸器系}

図 4 より, 心拍, 呼吸, 血圧の各機能の平均值は, 作業開始とともにエネルギー代謝が増大化し, 急激な 上昇を示す.その後, 情動反応に対する抑制が働くこ とにより 20,21) 交感神経緊張から副交感神経緊張が優 位の状況となり, 作業負荷と徐々に対応したかたちで バランスをとりながらほほ定常に推移する. そして, 動作に対する循環・呼吸器系の適応反応などにより, 心拍数は開始後約 30 分頃から緩やかな低下傾向を示 し, 開始後約 50 分頃から低下の傾向はやや大きなもの となる. 呼吸数では, 開始後約 40 分頃までの変動に比 べ, それ以後少ないものとなる. 血圧值は, 開始後約 30 分頃から拡張期血圧が下降傾向となり, 収縮期血圧 も開始後約 50 分頃から低下寸る. そして開始後 60 分 頃から収縮期血圧, 拡張期血圧がともに上昇傾向を示 す．以上はいちおうの傾向を示すものと考えられるが， より客観的な傾向を判断することは容易ではない.

\section{（2）筋骨格系}

血流量は, 開始とともに打鍵作業による筋活動が活 発となり, 酸素供給の増加とともに組織代謝が進み急 激な上昇を示す. その後, 組織の酸素要求にみあった 循環動態を, 細動脈の拡張というかたちで維持するた め定常推移となる.一方, 皮膚表面温度は, 打鍵動作 による放熱発散, 筋緊張による血管収縮となり, 急激 な低下 ${ }^{22)}$ を示す.その後, 血流量の増加とともに熱放散 が促進され, 熱産生と熱放散のバランスを保ちながら 定常推移し, 開始後 40 分頃から緩やかな低下傾向へと 変化する.さらに, 血流量や皮膚表面温度の二次的な 変動と考えられる皮膚色は, 開始とともに CIE 色度図 上での $\mathrm{x}$ 色度值が上昇し, $\mathrm{y}$ 色度值は下降する。これ らの変化は $\mathrm{x}-\mathrm{y}$ 色度図上では第 4 象限方向への変動 推移となる.

\section{(3) $\mathrm{CFF}$ 值}

CFF 值は, 作業開始とともに初期情動反応によって その興奮性が促進されるため, 覚醒水準はいちど上昇 するが, その後, 急激な下降傾向となる.

\section{(4) 視 力}

遠用視力値 $(5 \mathrm{~m})$ において作業前後の値を比較する と, 左・右眼で平均 0.2 , 両眼では平均 0.1 の低下がみ られた.これは CRT 画面の注視によって調節機構に 変化が生じるためと考えられる ${ }^{19)}$. 実験終了時では, 作 業終了直後に比べ左・右眼とも平均 0.1 上昇している が, 両眼視力では変化はみられない. よって, 作業後 

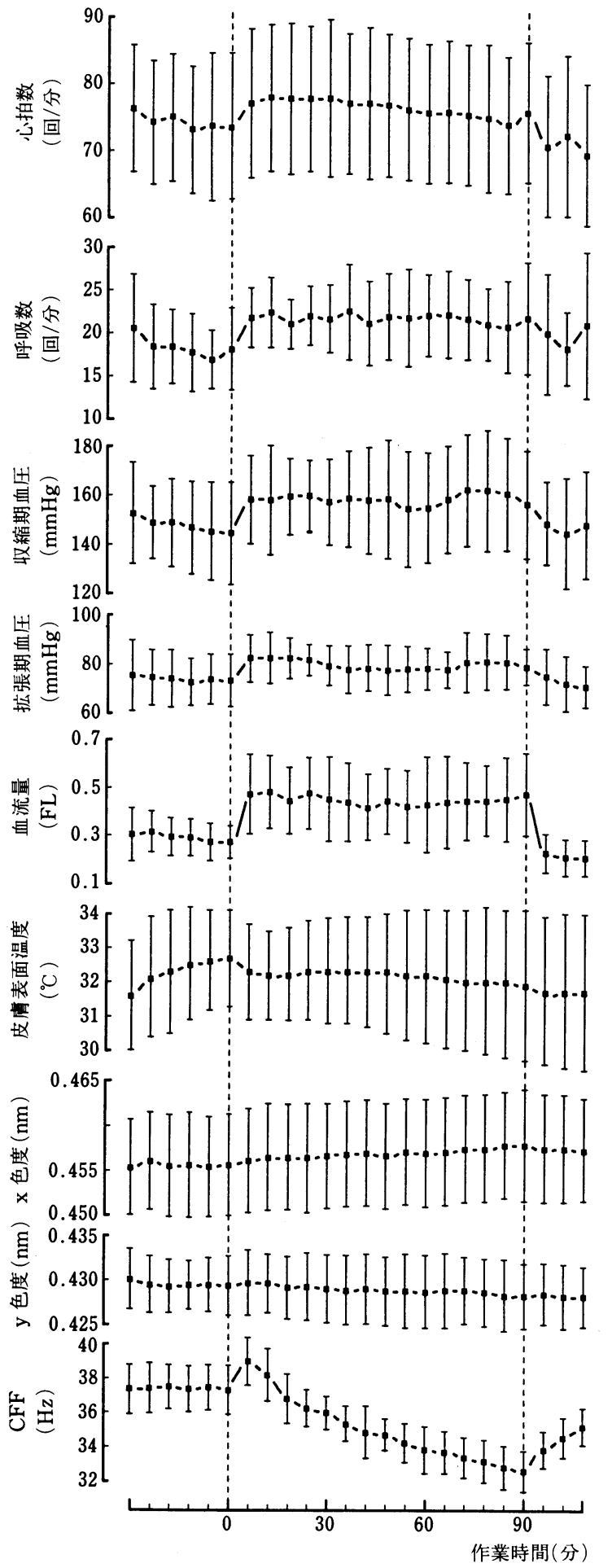

図 4 各指標の平均值の変化

Fig. 4 Changes in the mean values of each index.
の安静 20 分では視機能は完全に回復されないと考え られる。

また近用視力 $(50 \mathrm{~cm})$ は，左・右眼とも作業前後で 平均 0.1 の低下を示したが，有意な低下とはならなか った.

\section{3-2. 作業能}

図 5 より，正答率 $(\mathrm{N}-\mathrm{N})$ は開始とともに定常に推 移するが, 開始後約 30 分頃から下降傾向となり, 開始 後約 40 分頃が大きな変動ポイントとなることがうか がえる．これは図 6 での誤答率 $(\mathrm{N}-\mathrm{Y})$ の変化とよく 対応し, 開始後約 30 分頃から増加傾向となり, 40 分頃 を境に誤答率 $(\mathrm{N}-\mathrm{Y})$ は一段高いレベルとなって推移 する. Cushman ${ }^{23)}$ は 45 分頃を境に認識 (判読) 時間が 急激に大きくなるとしており, 今回の作業継続に伴う 作業能の変化では，いわゆる正答 (Y-Y) 作業に比べ て, 出現確率が低く $(20 \%)$, 上り高い認識集中が要求 される正答 $(\mathrm{N}-\mathrm{N})$ 作業比率による判断が妥当と考え られ, 40 分頃の変動変化と対応するものと考える. 無 答率は開始直後から低いレベルでの推移となり, 約 30 分頃から緩やかな増加傾向で, 誤答率と比べて変化の 程度は少ないが，正答率の低下との対応がみられる。

\section{3-3. 自覚症状調査}

図 7 より，作業前と作業後での有訴項目を比較する と“目が疲れている，物がぽやけて見える，目がちか ちかする”といった視覚系疲労に関する症状の訴えと， “腕がだるい，指がだるい”といった筋骨格系の肉体的 疲労要因の訴え, “体がだるい, 脱力感, 頭がほんやり している”といった精神的疲労要因の訴え率が有意な 増加となっている。また「どの症状が作業に影響しま したか」の問いには，視覚的疲労や精神的疲労と考え られる項目をあげる者が多かった。自覚症状調査の結 果から，作業を継続する過程において，項目間の有訴 時期に若干のずれが存在するが，大半は視覚系疲労， 筋骨格系疲労, 精神・神経系疲労などの疲労を感じ, その発現時期は作業中頃に最も集中した有訴となって いる.

\section{4. 考 察}

\section{4-1. 実験 I の考察}

循環・呼吸器系では，初期六進もみられるが，作業 開始後約 50 分頃からの生体各機能の低下変動は単調 繰り返し作業動作の性質に起因した大脳の機能抑制か らくる生体の活動抑制によるもの ${ }^{20,21,24)}$ と考えられる。 


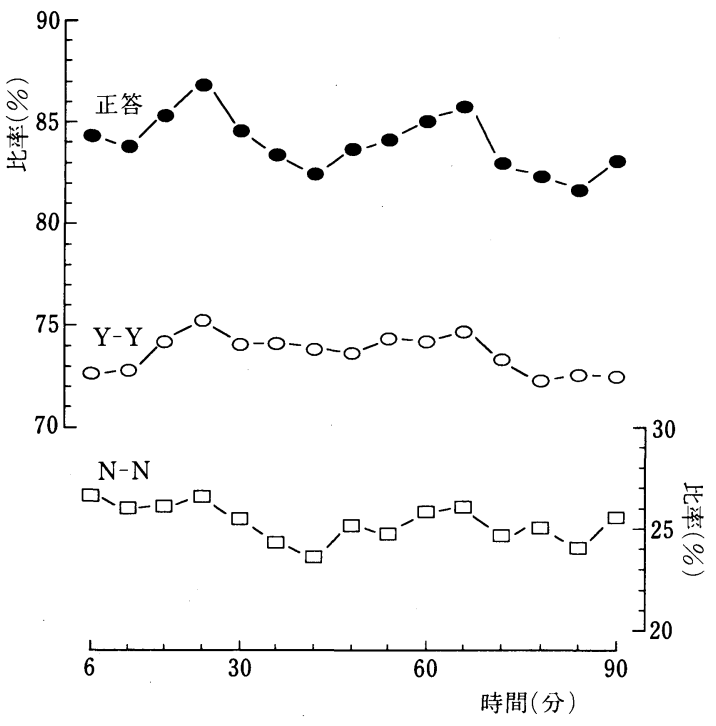

図 5 正答率の変化

Fig. 5 Changes in the mean correct answer rate.

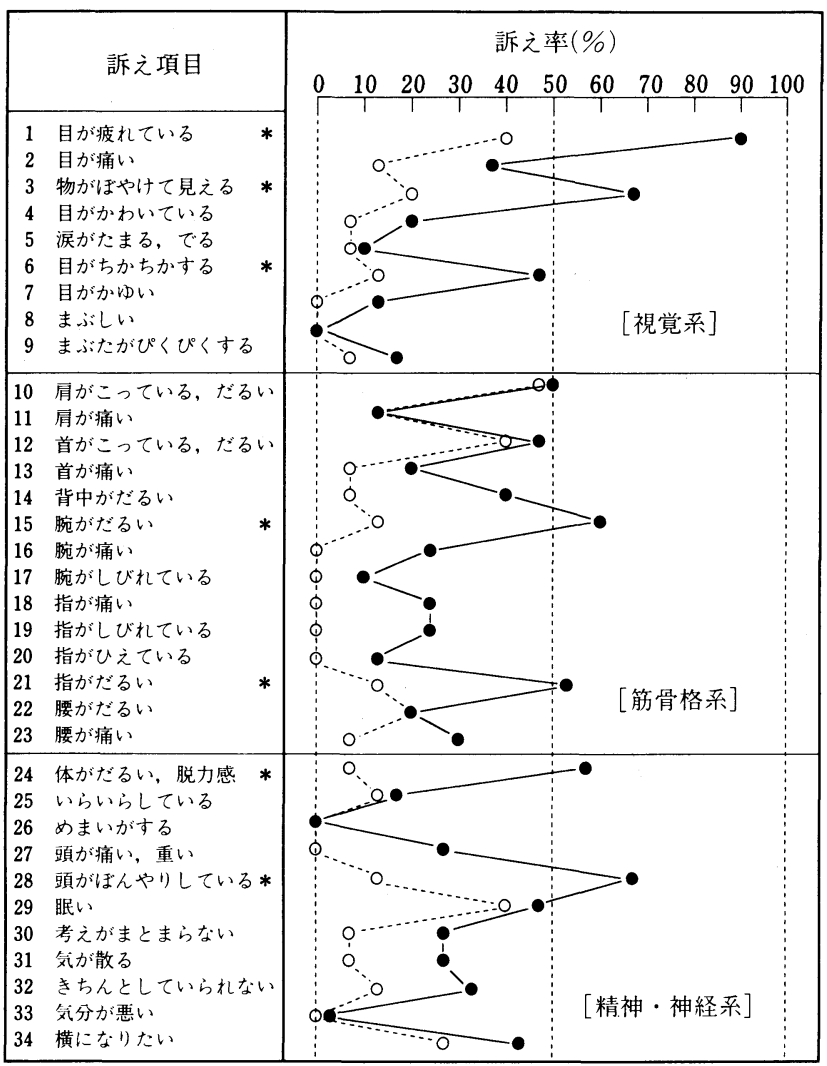

○一O作業前 $\bullet-\longrightarrow$ 作業後

図 7 疲労自覚症状調査結果の比較

Fig. 7 Comparison the investigations of subjective symptom of fatigue.

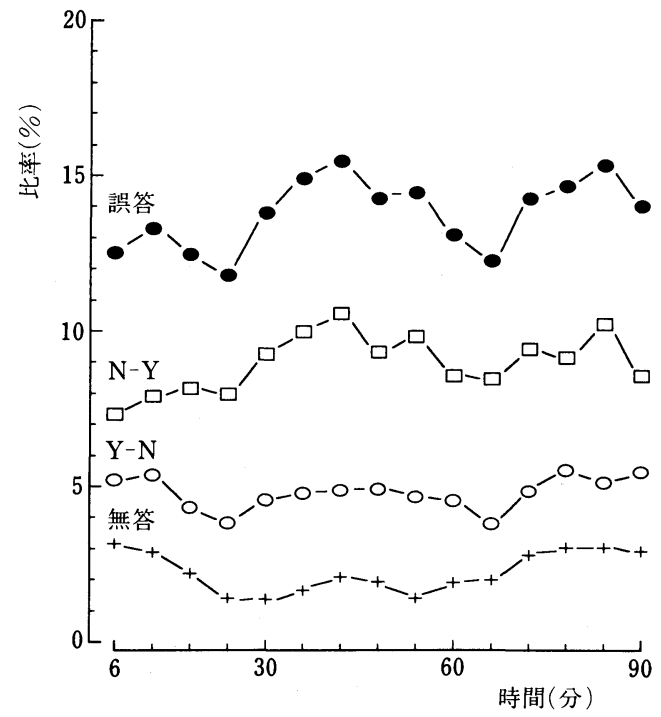

図 6 誤答率と無答率の変化

Fig. 6 Changes in the mean incorrect answer and mean no answer rate.

筋骨格系でも開始後約 40 分頃から末梢循環 がわるくなり, 皮膚温の低下, 皮膚色の変動 変化がみられる. しかし, それら各単一指標 の総合化で判断・評価を行うには, 同一条件 での反復測定と被験者数を多くすることが必 要とされ ${ }^{25)}$, 今回の指標特性でも, 変化水準・ 傾向が若干異なることから，一意的な評価・ 判定をすることは難しい. そこで, 同一評価 基準で各指標を比較・判断することを目的に, 各指標データの標準得点化により同一尺度化 した. 各機能測定値の標準得点 (standard score)への変換は, 各測定值の標準值 (基点) をその各指標測定值の平均におき, 各測定値 がその指標平均值からどの程度偏位している かによって表現されるものである。

標準得点化した各生理的機能の変動におい て, 生体の機能調節などにより, 中枢神経系 を含む中枢性要素が関与し, 正方向への変化 は生体機能の促進的な働きを，負方向への変 化は抑制的な働きを示す5,18,20,21,24) と判断す ることができよう。

各機能データの標準得点の時系列変動を示 した図 8 では, 作業開始とともに大きな変動 を示していた各指標が, 徐々に収束しながら, 活動の促進の場から緩やかに抑制の方向に推 移する. その後, 開始 $40 \sim 50$ 分頃に各機能が 


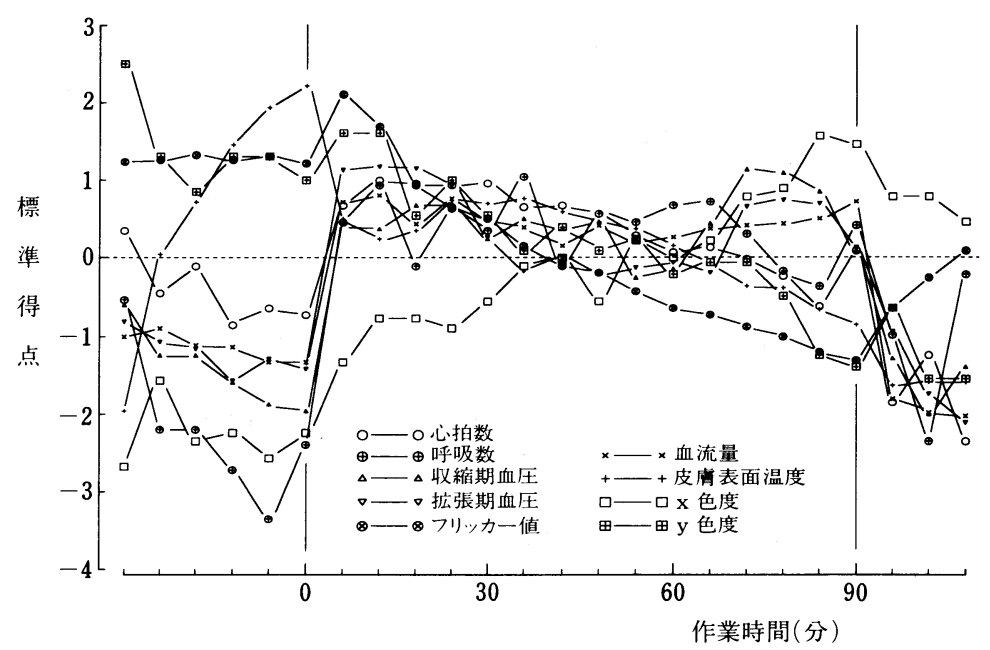

図 8 各指標の標準得点の変化

Fig. 8 Changes in the standard scores of each index.

収束傾向となる.そして開始 60 分頃から生体の機能調 節の自律性がくずれ ${ }^{20)}$, 各標準得点のバラツキが増大 化傾向となる．このように時間的な変動経過をたどっ て定常状態のくずれかたや, ある比率以上の変化が生 じる時点や持続時間などを評価することの有効性につ

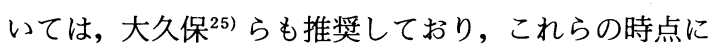
生理的機能変動の時期が存在すると推察される.

さらに, その変動時期とその前後の状況をより明確 に判断するために, 全標準得点を作業時間別平均值お よび標準偏差に統合化して図 9 に示す。これより, 作 業前では安定的に推移していた各機能の平均値は, 開 始とともに急立進し，その後もゆっくり機能の抑制方 向へと変化する.そして開始後約 60 分頃からほほ定常
推移となり,その傾向が開始 60 分頃を境に明確な変化 となる.一方，標準偏差では開始前での大きな変動か ら，作業開始とともに急激な減少および下降傾向とな るが, 開始後約 40 分過ぎから 50 分頃を境に上昇傾向 に転じ, 再びそれが大きく変動変化する. 平均值では, 開始後約 60 分頃にその傾向の明らかな変化が認めら れるのに対し，標準偏差ではそれより 10 分から 20 分 前に大きな変化傾向となる. よって, 各生体機能の変 動は, 標準偏差にその兆候がまず現れ, ついで平均値 の変動によって, 統一的で具体的な現象(ひずみ) ${ }^{15)}$ と なって明確化するものと考元られる。さらに作業の質 的・量的変化も, 開始後 40 分頃とほほ同傾向の変動発 現時期と推察される.さらに自覚症状調查でも, 有訴

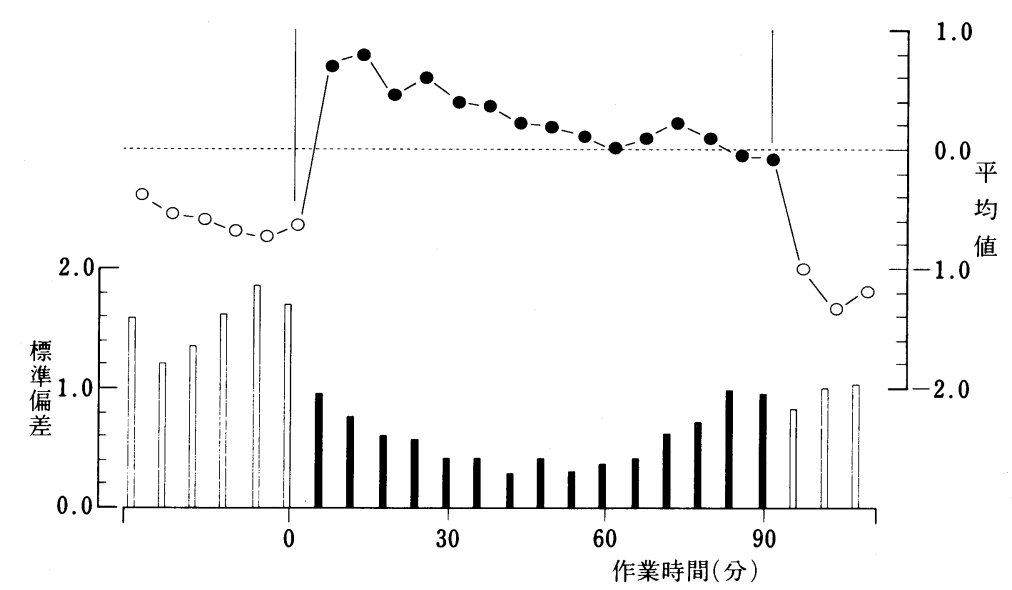

図 9 標準得点の平均値と標準偏差の変化

Fig. 9 Changes in the mean values and standard deviations of standard score. 


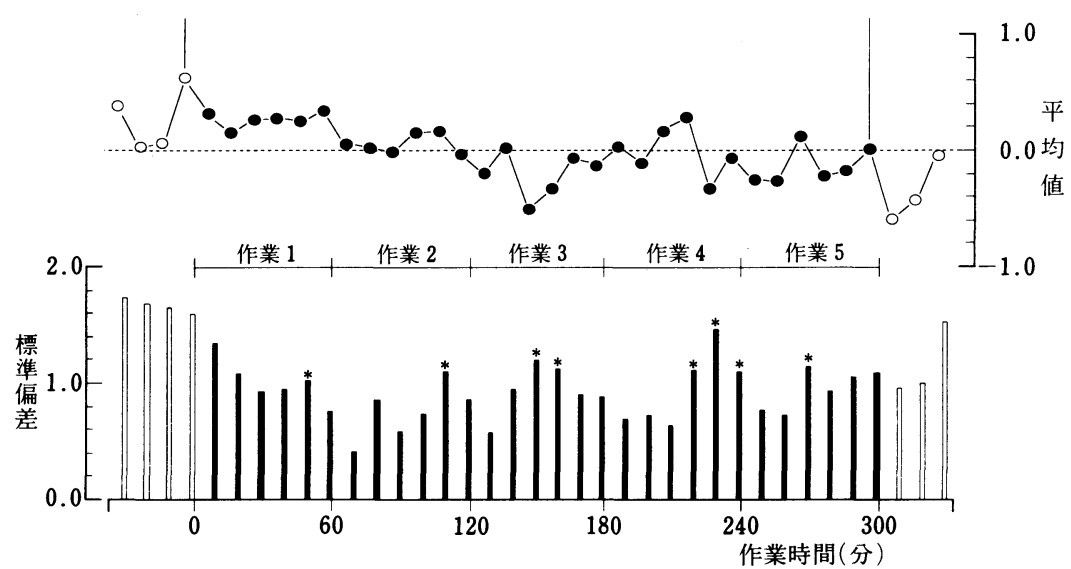

図 10 標準得点の平均値と標準偏差の変化（実験 II）

Fig. 10 Changes in the mean values and standard deviations of standard score (Experiment II).

率が作業中頃から高くなっている。これらの結果は, 堀江 ${ }^{26)}$ や三澤 ${ }^{27)}$, および労働省の VDT 作業のガイド ライン ${ }^{28)}$ などと同方向であると判断される。よって, 生理的機能の統合化, 作業能および自覚症状調査の 3 側面からの総合的評価により, 開始後 40 分から 60 分 頃に活動水準の低下による恒常性の維持が乱れ, 疲労 発現と推察される傾向が示される.

\section{4-2. 実験 II の考察}

実験 I の結果を踏まえ, 生理心理機能における各指 標標準得点の平均值・標準偏差の推移から考察する.

図 10 より, 平均値では開始後 60 分から 120 分頃へ と, その值は低下傾向を示すものの, ほほ定常に推移 する．その後，約 300 分頃まで大きな変動傾向となり， 作業継続とともに生体機能群が不安定な推移となるこ とが理解される，作業区分別では，作業 1 で安定的に ほほ定常推移し, 作業 2 では作業 1 に比べてややレべ ルの低下も認められるが, ほほ定常推移に近いと考え られる. 作業 3 ではさらにレベルが低下し, 開始後約 30 分から 40 分頃に大きく低下する. その後, 作業 4 で は回復の兆しが若干みられるが変動の程度は大きく, 開始後約 40 分から 50 分頃にかけて急激な低下となる. 作業 5 では, 直前の 10 分休息では機能回復は可能とな らず，低いレベルで大きくばらついた推移変動となる. したがって, 作業 1 , 作業 2 でほほ定常的に推移して いた各機能が, 作業 3 以降では変動が増大化し, 機能 変動が明確な傾向となって示される.

標準偏差の推移を作業区分別にみると，作業 1 では 作業開始とともに低下傾向となるが, 開始後約 40 分頃 から 50 分頃に大きな変動が示される.作業 2 でも同時 期の変動傾向となり, 実験 $\mathrm{I}$ の結果と同様の傾向を示
す. 作業 3 では, 開始後約 30 分から 50 分頃にかけて 変動が大きなものとなる.作業 4 でも開始後約 40 分頃 から 50 分頃にかけて, バラツキが増大化する.さらに 作業 5 では, 開始後 30 分頃にはばらついた変化とな る. よって標準偏差の推移から判断すると, 作業 1 , 作業 2 では開始後約 40 分頃からの変動となり, 作業 3 , 作業 4 , 作業 5 では開始後約 30 分頃から変動が増 大化する。

さらに，作業区分別の標準得点の標準偏差を作業時 間帯別に積み重ねた図 11 より, 作業開始後 40 分から 50 分頃の値が有意に高くなり, 統合化することにより 各生理的機能変動の推移が明確なものとして示される. 作業態様が局所筋の動作を伴う単純繰り返し視覚検索 型の VDT 作業において, 一連続作業時間 60 分ごとに 10 分間休款の作業方式では, 徐々に機能変動の時期が 早くなり，作業を繰り返し継続することに問題が存在 することが予測される。

以上の結果より，こまかな閾値の変化を把握する感 度はそれほど高くないが, 標準得点の平均值の推移は 機能全体の推移レベルを示し, 標準偏差の推移はその 機能レベルの変化を明確にとらえることが可能と考え られる.これは, 高桑 ${ }^{16)}$ のいう疲労評価にあたって質 的に全く異なる指標の重みづけ問題と，それらの数的 な表現という目標に若干踏み出せたものと考える.

\section{5. おわりに}

実験 I と実験 II を総合して, 今回の視覚検索型 VDT 作業において, 生理的機能を統合化することで, 作業開始後 40 分頃から 50 分頃 (標準得点の標準偏差) に機能調節の自律性のくずれの兆候が出現し, その後, 


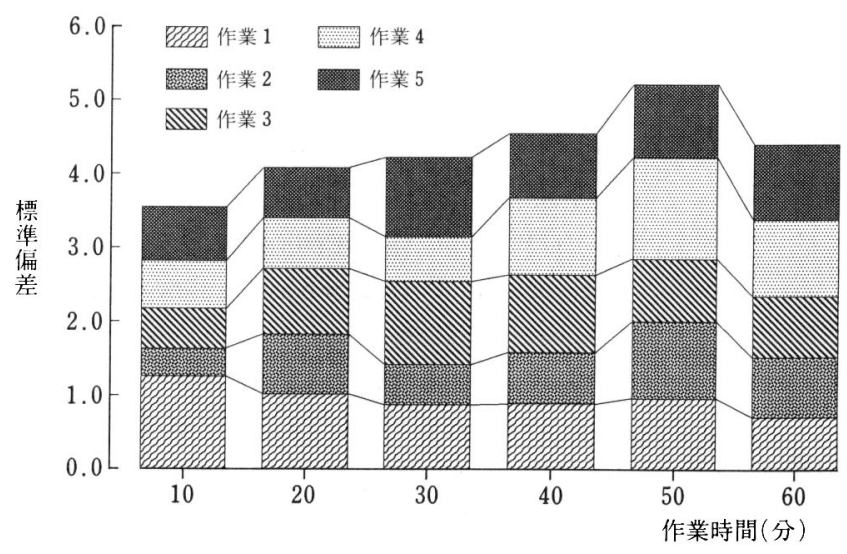

図 11 作業別による標準得点の標準偏差の 変化 (実験 II)

Fig. 11 Changes in the standard deviations of standard score by the work distinctions (Experiment II).

60 分頃 (標準得点の平均値) にかけて具体的な現象 (ひ ずみ）と考えられる機能変動となることが推察された。 作業の質的・量的変化では, 開始後約 40 分頃が変動発 現時期と判断され, 加えて, 自覚症状調査でも有訴率 が作業中頃から高くなることが検証された。よって， 生理的機能の統合化, 作業能, および自覚症状調査の 3 側面の総合的な評価より, 開始後約 40 分から 60 分 頃が, 疲労による恒常性維持の乱れの発現時期と判断 することができる。

また実験Iににいて,各作業サイクル開始 40 分から 50 分頃にかけて標準得点の平均值・標準偏差に変化が 現れ, 繰り返し実施の場合では, 一連続作業時間 60 分 に 10 分間の休喤挿入では, 徐々に機能変動時期が早く なり, 10 分間の休㮩では, 今回の作業を継続すること は適切ではないことが推察される. 各指標の標準得点 の平均值および標準偏差の推移から, その傾向が明確 なものとなり, 機能変動の統合的な評価で, 疲労の客 観的判定の可能性が認められる.

以上，生理心理的機能に扔いて，指標データそのも の全体から機能変動の統一的な方向性を判断すること は, 各指標デー夕の変化特性, 水準などによりあまり 期待できない.そこで各生理心理機能デー夕の標準得 点を統合化した, 平均值と標準偏差の推移により, 機 能の調整がとれなくなり始めた状況 ${ }^{15)}$ が明確なかた ちとなることが示された．さらに，作業能および自覚 症状調査の結果と併せて総合的に判断することで, 疲 労の判定指標としての妥当性が推察された. 今後は, 標準得点の平均值, 標準偏差デー夕の検証・検討の方 法, その判定基準をより明確化する方途，および一連 続作業時間と休㕷時間の最適配分問題などが課題であ る.

本研究を進めるにあたって, 実験データの収集や解
析に関して, 大学院生 渥美要一氏 (現アスモ(姝) に多 くの協力を得た．ここに謝意を表する.

\section{参考文献}

1）大中忠勝：中高年者の作業特性, 岡田 明：産 業疲労, 田中正敏, 菊池安行編：近未来の人間科 学事典, 326, 334 338, 朝倉書店, 1988.

2) 井谷 徹, 大谷 透浪：VDT 作業時間分布 と作業負担に関する研究, 労働科学, 65(6), 356 364, 1989.

3) Smith, M. J., Cohen, B. F. G., Stammerjohn, L. W. and Happ, A. : An Investigation of Health Complaints and Job Stress in Video Display Operations, Human Factors, 23(4), 387 400, 1981.

4) Matula, R. A. : Effects of Visual Display Units on the Eyes: A Bibliography, Human Factors, 23(5), 581 586, 1981.

5）斉藤 進：OA 用ディスプレイの生理的問題, 照明学会誌, 68(3), 10 14, 1984.

6) 斎藤和雄: 精神的疲労測定の新しい考方方とそ の方法, ENGINEERS, 514, 18〜21, 1991.

7) Lagrange, F. : Physiologie des exercises du corps, Felix Alcan, Paris, 1904.

8）猪飼道夫, 山川純子：急速反復動作における疲 労の現われ方, 体育学研究, $2,168 \sim 173,1951$.

9）横堀 栄：スポーツと疲労, 体育の科学，12, $130 \sim 134,1962$.

10）横堀 栄: 疲労の本態とその対策, 公衆衛生, 21, 20〜26, 1962 .

11) Christensen, E. H. : Fatigue of the working individual, Academic Press, 455 465, 1960.

12) Ryan, T. A. : Varieties of fatigue, Am. J. 
Psychol., 57, 565 569, 1944.

13) Bills, A. G. : Various Views on Fatigue, Fatigue and Impairment in Man : Bartley, H., Chute, E., McGraw-Hill Co., 1947.

14）橋本邦衛：疲労，人間工学ハンドブック編集委 員会：人間工学ハンドブック，453, 金原出版, 1966.

15）大島正光：疲労の研究，同文書院，1979.

16）万木良平：環境適応の生理衛生学, 9 12, 朝倉 書店, 1989 .

17）斎藤和雄：29 産業疲労,高桑栄松：30 集中維持 機能一特論一, 藤原元典, 渡辺厳一, 高桑栄松編： 総合衛生公衆衛生学(下), 1196 1206, 南江堂, 1985.

18）上山章光：循環機能の調節, 古河太郎, 本田良 行編：現代の生理学, 478 485, 金原出版, 1982 .

19）日本産業衛生学会・産業疲労研究会編集委員 会：産業疲労ハンドブック，146〜 169，353～357, 労働基準調查会, 1988 .

20）本川弘一, 和田正男編：藤田佐武生理学講義 (上), 13 19, 南山堂, 1970 .

21）猪飼道夫：IX 適応協関の生理学, 吉村寿人ほか
編：生理学大系, 709 717, 医学書院, 1970.

22）中山昭雄, 丹羽健市：22 エネルギー代謝・体温 調節の生理学, 勝木保次ほか編: 新生理学大系, 309 313, 医学書院, 1987.

23) Cushman, W. H. : Reading from Microfiche, a VDT, and the Printed Page: Subjective Fatigue and Performance, Human Factors, 28 (1), 63〜 73, 1986.

24）橋本邦衛，遠藤敏夫：生体機能の見かた一人間 工学への応用一, $148 \sim 151$, 日本出版サービス, 1973.

25）大久保堯夫：人の評価技法, 大島正光, 大久保 堯夫編：人間工学, 49 64, 朝倉書店, 1989 .

26）堀江良典：VDT 作業における一連続作業時間 と休䕀に関する研究, 人間工学, $23(6), 373$ 383, 1987.

27）三澤哲夫, 吉野賢治, 重田定義：VDT 作業の一 連続作業時間に関する実験的研究, 産業医学, $26(4), 296 \sim 302 ， 1984$.

28）労働省労働基準局安全衛生部労働衛生課： VDT 作業における労働衛生管理, 労働の科学, 39(11), 4〜8, 1984. 